\title{
EXTRACTION OF POLYPHENOLIC COMPOUND FROM TOMATOES PEEL AS NATURAL ANTIOXIDANT TO BE KEEPING CAKE QUALITY DURING STORAGE.
}

\author{
SANDAK, R.N., A. S. I. EL- SHAZELY AND SOHIER T. EL-HADIDI
}

Food Tech. Res. Inst., ARC, Giza

(Manuscript received 29 July 2008)

\begin{abstract}
Tomato peel was treated by ethanol $70 \%(\mathrm{v} / \mathrm{v})$ to extract flavonoids (kaempferol, quercetin, lutolin, narginine and rutin) and phenolic acids ( $P$-coumaric, ferulic and chlorgenic acids) were identified by paper charomatographic technique. Natural and synthetic (butylated hydroxyanisol, BHA) antioxidants exhibited strong and close antioxidative activities 85.85 and $92.60 \%$, respectively. The tomato peel extract and BHA were added to sunflower oil at levels 100,150 and $250 \mathrm{ppm}$ to keep its quality during heating at $180^{\circ} \mathrm{C}$ for 32 hours. Moreover, the natural and synthetic antioxidants were added to cake made up by sunflower oil at the same levels. Cake was stored at room temperature for four weeks and the lipids were extracted every four days.

The results showed that the addition of tomato peel extract as natural antioxidant to sunflower oil and cake delayed the lipid peroxidation during heating oil and storage of cake.
\end{abstract}

\section{INTORDUCTION}

Tomatoes (Lycopersum esculentum) are widely consumed either raw or after processing and can provide significant properties of total antioxidants in the diet. This is largely in the form of carotenes and polyphenolic compounds (Clifford,1999).

Moreover, tomato- processing by product, also known as tomato pomace, consisting of peel and seeds and represents around $4 \%$ of the fruit weight. If these wastes remain unused, they not only add to the disposal problem but also aggravote environmental pollution (Valle et al.,2006).Tomatoes peel contains flavonoids mainly naringenin chalcone and the flavonol rutin , quercetin glycoside. Flavonols are very potent antioxidants and their dietary intake is correlated with a reduced risk of cardiovascular diseases ( Bovy et al., 2002).

Flavonoids from a large group of polyphenolic compounds that occur naturally in plants. Based on their core structure. The aglycone, they can be grouped into different classes, such as chalcons, flovanones, dihydriflovnols, flavonols and anthocyanins. To over 4000 different flavonoids have been identified. This large diversity is attributable to single or combinatorial modifications of the aglycone, such as glycosylation, methylation and acylation. As a group, flavonoids are involved in many aspects of plant growth and development, such as pathogen resistance, 
pigment production, ultraviolet light protection, pollen growth and seed coat development (Harborne, 1986).

There is increasing evidence to suggest that flavonoids, in particular those belonging to the class of flavonols (such as kaemplerol and quercetin) are potentially health -protecting components in the human diet as a result of their high antioxidant capacity (Duthie and Crozier , 2000) and their ability, invitro, to induce human protective enzyme systems (Shih et al., 2000).

Lipid peroxidation in fats and fatty foods not only causes chemical spoilage in foods but also produces free radicals active oxygens such as peroxyl and radicals (Tagi, 1987). Free radical attack the unsaturated fatty acids in the biomembrane, resulting in memberane lipid peroxidation, decrease in memberane fluidity, loss of enzyme and receptor activity and damage to memberane protein leading to cell inactivation. Also, free radical attack DNA cause mutation leading to cancer (Diplock et al., 1994). Likewise, Duh and Yen (1997) cited that the addition of the antioxidants to food is effective in retarding fat oxidation. It is impressive that many substance have been identified which prevent lipid peroxidation. Some of these compounds are synthetic antioxidants and others occur as natural dietary constituents.

The present investegation aimed to isolate and identify flavonoid and phenolic compounds from tomatoes peel as a waste of low cost. Also, to study the effect of nartural antioxidants (flavonoid and phenolic compounds) to prevent liped peroxidation in sunflower oil and cake and to compare their effect to butylated hydroxyanisol (BHA).

\section{MATERIALS AND METHODS}

\section{Materials :}

Tomatoes peel were obtained from Kaha Company for Preserved Foods, Kalubeia, Egypt. The peels were dried in an oven at $60^{\circ} \mathrm{C}$ and finely ground.

Butylated hydroxyanisol (BHA) was obtained from Noarden International Company Holland. Whilest, authentic flavonoid and phenolic compounds were purchased from Sigma Chemical Company, Deisenhofen Germany.

Sunflower oil was obtained from Arma Food Company, EL- Asher of Ramodan , Egypt.

\section{Mathods :}

Extraction, isolation and purification of polyphenolic compounds from tomatoes peel:

Air dried tomatoes peel $(500 \mathrm{~g})$ was finely powdered and extracted with petroleum ether $\left(40-60^{\circ} \mathrm{C}\right)$ to remove fats and resinous materials. The residue was exchustively 
extracted with two liters $70 \%$ ethanol by heating on a boiling water bath for six hours. Extraction was repeated until a color extract then the extracts were combined and concentrated to obtain aqueous ethanolic extract. A brown product was obtained upon evaporation of ethanol to dryness and kept for flavonoid and phenolic compounds investigation according to Mebry et al., (1970).

The brown extract of tomatoes peel were tested by paper chromatographic technique in order to identify the major flavonoid and phenolic compounds as described by Markham and Mabry (1968).

The tomatoes peel extract and authentic samples were spotted on one dimensional Whatman no., 1 paper chromatoghraphy. The eluting solvents were butanol: acetic acid: water (4: 1: 5) and acetic acid 15\% (ACOH). The different spots (major flavonoid and phenolic compounds and authentic samples) were located by color reaction and $\mathrm{R}_{\mathrm{F}}$ values under U.V. lights with and without the presence of $\mathrm{NH}_{3}$ fumes were calculated according to Markhan and Mabry (1968).

\section{Determination of Antioxidant activity :}

Flavonoid and phenolic compounds were evaluated as antioxidant activity of the previous extract from tomatoes peel and compared with butylated hydroxyanisol ( BHA) by thiocyante method as described by Tsuda et al., (1993).

\section{Addition of antioxidant to sunflower oil:}

Sunfower oil was used as a substrate for oxidations studies. Natural antioxdant extracted from tomatoes peel and synthetic antioxidant (BHA) were added to oil at 100,150 and $250 \mathrm{ppm}$ on a dry weight basis to test thier antioxidant effectiveness according to Buford (1988). Control sample without additive was prepared under the same conditions.

Sunflower oil with and without antioxidant (natural or synthetic) was heated in 500 $\mathrm{ml}$ glass beaker at $180^{\circ} \mathrm{C} \pm 5^{\circ} \mathrm{C}$ for $32 \mathrm{~h}$. (total heating hours) intermittent heating period was $4 \mathrm{~h} /$ day.The oil samples after heating were taken periodically and stored in glass bottles at $-10^{\circ} \mathrm{C}$ till analysis.

\section{Preparation of cake:}

The ingredients of oil cakes are given in Table (1) according to Mizukoshi, et al., (1979) with little modification, the foaming agent was substaituted by baking powder and vanillia. Natural and synthetic antioxidants were added to the oil cakes at 100, 150 and 250 ppm levels. Suger, whole egg, vanillia , paking powder and water were mixed for $5 \mathrm{~min}$ flour was added and mixed for $10 \mathrm{~min}$ in a mixer. The product was baked at $191^{\circ} \mathrm{C}$ for $25 \mathrm{~min}$ in an electric oven and the cake was stored in refrigerator at 5.0 $\mathrm{C}$ and packaged in polyethylene bags for four weeks. 
Table 1. Ingredients of cake made using sunflower oil

\begin{tabular}{|l|c|}
\hline \multicolumn{1}{|c|}{ Ingredients } & Weight /g \\
\hline Flour & 200 \\
\hline Sugar & 250 \\
\hline Whole egg & 150 \\
\hline Vanillia & 1 \\
\hline Baking powder & 13 \\
\hline Water & 40 \\
\hline Sunflower oil & 100 \\
\hline
\end{tabular}

\section{Extraction of the oil from cake:}

Oil was extracted from cake samples every four days by soaking in $n$-hexan at room temperature for $48 \mathrm{~h}$. The extract was filterated and evaporated to dryness. The extracted oils were kept in the deep-freezer for further investigations.

\section{Physico-chemical characteristics of oil :}

Peroxide value ml.equivints $/ \mathrm{kg}$ oil was determined in heated sunflower oils and in the extracted oils from cakes according to AOAC. (2000).

\section{Statistical analysis:}

The results from heated sunflower oils and extracted oils were statistically analyzed according to Steel and Torrie (1980).

\section{RESULTS AND DISCUSSION}

\section{Chromatographic analysis of tomatoes peel extract:}

The components of tomatomes peel extract were identified with paper chromatographic techniques and compared with authentic samples. The solvents used, (were butanol: acetic acid: water) (4: 1: 5) and acetic acid ( $\mathrm{ACOH}, 15 \%)$. The color and $R_{F}$ values of the flavonoid and phenolic compounds are shown in Table (2). The ethanolic extract was found to contain five flavonoid compounds (kaempferal, quercetin, lutolin, nargenin and rutin) and three phenolic acid compounds ( $P$. coumaric, ferulic and chlorogenic acids). These results are agreemented with Martinez-Valvarde et al., (2002), who found that the content of phenolic compounds in tomatoes peel were characterized as flavonoids (quercetin, kaemferol and nargenin) and hydroxycinnamic acids (caffeic, chlorogenic , ferulic and p-coumaric acids).

\section{Antioxidant activity of tomatoes peel extract:}

The efficiency of natural antioxidants of tomatoes peel extract was compared with synthetic antioxidant (butylated hydroxyanisol, BHA) measured by thiocyanate method 
and the results are reported in Table (3). The natural and synthetic antioxidant showed strong antioxidant activety 85.85 and $92.60 \%$, respectively. Lipid per oxidation occurred by oxidation of fatty acids in the presence of enzymes and by exposure to reactive oxygen species and to transition metal ions in a free radical chain reaction. Phenolic compounds, because of their structure are very efficient scavengers of free radicals (Gazzani et al., 1998).

Table 2. polyphenolic compounds of tomatoes peel extract

\begin{tabular}{|c|c|c|c|c|}
\hline \multirow[b]{2}{*}{ Compounds } & \multicolumn{2}{|c|}{$R_{\text {Fvalue }}$} & \multirow{2}{*}{$\begin{array}{c}\text { Without } \mathrm{NH}_{3} \text { Fumes } \\
\text { U.V }\end{array}$} & \multirow{2}{*}{ 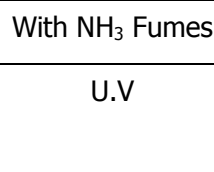 } \\
\hline & BAW & $\begin{array}{l}\mathrm{ACOH} \\
15 \%\end{array}$ & & \\
\hline \multicolumn{5}{|l|}{ Flavonoids } \\
\hline Kaempferol & 82 & 1 & Yellow & Bright yellow \\
\hline Quercetin & 65 & 4 & Yellow & Bright yellow \\
\hline Lutolin & 87 & 67 & Dark brown & Yellow \\
\hline Narginin & 88 & 3 & Deep purple & Greenish purple \\
\hline Rutin & 44 & 56 & Deep purple & Yellow \\
\hline \multicolumn{5}{|l|}{ Phenolic acids } \\
\hline$p$-Coumaric acid & 69 & 92 & Faint & Violet \\
\hline Ferulic acid & 74 & 54 & Blue - violet & Green \\
\hline Chlorognic acid & 62 & 62 & Blue & Green \\
\hline
\end{tabular}

BAW Butanol : Acetic acid : Water

$\mathrm{ACOH}$ Acetic acid

U.V. Ultra violet light

Table 3. Antioxidant activity of tomatoes peel extract compared with BHA.

\begin{tabular}{|c|c|c|c|}
\hline & $\begin{array}{l}\text { Absorbance at } \\
500 \mathrm{~nm} .\end{array}$ & $\begin{array}{c}\text { \% lipid } \\
\text { peroxidation }\end{array}$ & Activity \% \\
\hline No additive & 0.65 & 100 & 0.00 \\
\hline $\begin{array}{c}\text { Tomato peels } \\
\text { extracts }\end{array}$ & 0.092 & 14.15 & 85.85 \\
\hline BHA & 0.048 & 7.38 & 92.60 \\
\hline
\end{tabular}

BHA Butylated hydroxyanisol.

\section{Peroxide values in heated and extracted oils:}

The peroxide value is a good index for the quality of fat. Refined fats should have peroxide value of less than 1 millequivalant / $\mathrm{kg}$. Fats that have been stored for some period of time after refining may have peroxide value up to 10 millequivalent / $\mathrm{kg}$ oil ( Rossell, 1983). 
Table (4) showed the treatment of sunflower oil by heating at $180^{\circ} \mathrm{C}$ for $32 \mathrm{~h}$. with natural and synthetic antioxidants at different levels. From the results it could be observed that the natural and synthetic antioxidants at level $250 \mathrm{ppm}$ effectively inhibited the increase in peroxide value for a peroid of 32 hours heating from 0.26 to 12.1 and 9.5 mileque./ $\mathrm{kg}$, respectively. Little close effects were observed for the addition of BHA and natural antioxidants at $250 \mathrm{ppm}$. This means that tomatoes peel extract contained antioxidants (flavonoids and phenolic compounds) to retard lipid peroxidation during continous heating.

Table 4. Effect of antioxidants and heating temperature on peroxide value of sunflower oil.

\begin{tabular}{|l|l|l|l|l|l|l|l|}
\hline \multirow{2}{*}{$\begin{array}{l}\text { Heating } \\
\text { Period ( hr ) }\end{array}$} & \multirow{2}{*}{\begin{tabular}{l} 
Control \\
\cline { 3 - 8 }
\end{tabular}} & \multicolumn{5}{|c|}{ Natural } & \multicolumn{3}{c|}{ BHA synthetic } \\
\cline { 3 - 8 } & & $100 \mathrm{ppm}$ & $150 \mathrm{ppm}$ & $250 \mathrm{ppm}$ & $100 \mathrm{ppm}$ & $150 \mathrm{ppm}$ & $250 \mathrm{ppm}$ \\
\hline Zero & 0.26 & & & & & & \\
\hline 4 & 7.5 & 4.2 & 3.3 & 3.2 & 3.3 & 3.2 & 3.0 \\
\hline 8 & 9.7 & 5.3 & 4.0 & 3.7 & 4.1 & 3.4 & 3.2 \\
\hline 12 & 29.0 & 8.7 & 5.2 & 4.3 & 4.7 & 4.4 & 3.9 \\
\hline 16 & 33.4 & 15.4 & 6.3 & 5.1 & 7.1 & 5.1 & 4.5 \\
\hline 20 & 40.7 & 17.0 & 7.2 & 5.6 & 9.2 & 6.3 & 5.0 \\
\hline 24 & 56.4 & 19.7 & 9.1 & 6.7 & 12.3 & 8.1 & 6.1 \\
\hline 28 & 63.2 & 22.5 & 10.7 & 9.7 & 14.5 & 9.3 & 8.3 \\
\hline 32 & 73.1 & 25.3 & 13.1 & 12.1 & 17.8 & 11.5 & 9.5 \\
\hline L.S.D at 5\% & 0.03 & 0.07 & 0.04 & 0.09 & 0.05 & 0.12 & 0.16 \\
\hline
\end{tabular}

\section{Control sunflower oil free antioxidants}

Peroxide value of oils extracted from sunflower cake was determined every four days up to twenty eight days and the results are given in Table (5). From the results, it could be noticed that $250 \mathrm{ppm}$ of the tomatoes peel extract and BHA effectively inhibited the peroxide formation for a period of four days (p.v.2.4 to 2.7 and 2.3 to 2.6 millequ./ $\mathrm{kg}$ ). Then the peroxide value increased to 15.2 in natural antioxidant and $12.1 \mathrm{millequ} / \mathrm{kg}$ at the end of storage period. Very close results were observed for the addition of natural and BHA at $250 \mathrm{ppm}$. It is worth to mention that $250 \mathrm{ppm}$ from tomatoes peel extract also decresed the peroxide value.

From the aformationed results, it could be suggested that the addition of natural antioxidant from tomatoes peel at $250 \mathrm{ppm}$ delayed the peroxide value. 
Table 5. peroxide value of sunflower oil extracted from cake after baking as affected with tomatoes peel extract and BHA.

\begin{tabular}{|l|l|l|l|l|l|l|l|}
\hline \multirow{2}{*}{ Time /day } & \multirow{2}{*}{ Control } & \multicolumn{5}{|c|}{ Sunflower oil containing andtixoidants } \\
\cline { 3 - 8 } & & \multicolumn{5}{|c|}{} \\
\cline { 3 - 8 } & & $100 \mathrm{ppm}$ & $150 \mathrm{ppm}$ & $250 \mathrm{ppm}$ & $100 \mathrm{ppm}$ & $150 \mathrm{ppm}$ & $250 \mathrm{ppm}$ \\
\hline \multirow{2}{*}{ Zero } & 3.4 & 2.4 & 2.4 & 2.4 & 2.4 & 2.3 & 2.3 \\
\hline 4 & 5.1 & 3.5 & 3.1 & 2.7 & 3.3 & 3.1 & 2.6 \\
\hline 8 & 8.3 & 5.7 & 4.4 & 3.9 & 5.5 & 4.0 & 3.2 \\
\hline 12 & 11.7 & 7.2 & 6.7 & 5.7 & 6.8 & 6.2 & 4.8 \\
\hline 16 & 13.5 & 10.4 & 9.5 & 8.4 & 11.2 & 9.8 & 7.6 \\
\hline 20 & 15.2 & 13.7 & 12.3 & 9.7 & 12.5 & 11.8 & 9.3 \\
\hline 24 & 17.3 & 15.3 & 14.7 & 11.5 & 14.2 & 13.2 & 10.1 \\
\hline 28 & 20.2 & 17.0 & 15.2 & 13.1 & 16.5 & 13.7 & 12.1 \\
\hline L.S.D at 5\% & 0.683 & 0.476 & 0.580 & 0.535 & 0.436 & 0.692 & 0.478 \\
\hline
\end{tabular}

Before backing cake peroxide value of sunflower oil was 3.2 mel equ. $/ \mathrm{kg}$

\section{REFERENCES}

1. A.O.A.C. 2000. Association of Official Agriculural Chemists. Official Methods of Analysis 17 th ed., A.O.A.C, Washington, DC., USA.

2. Bovy, A., R. Vos, M. Kemper, E. Schijlen, M.A. Pertejo, S. Muir, G. Collins, S. Robinson, M. Verhoeyen, S. Hughes, C. S. Buelga and A. Tunen. 2002. High flavonol tomatoes resulating from the hetero logous expression of the maize transcription factor genes LG and C1. Plant cell, 14( 10): 2509- 2526

3. Buford, R. 1988. Extending shelf life by using traditional phenolic antioxidants. Cereal Food World , 32(2) :207-212

4. Clifford, M. 1999. Chlorogenic acid and other cinnamates nature, occurrence and dietary burden. J.Sci.Food Agric., 79: 362.372.

5. Duthie , G. and A.Grozier. 2000. Plant-derived phenolic antioxidants. Curr.Opin. Lipidol. 11: 43-47

6. Diplock, A.T., C.A. Rice - Evans and R.H. Burdon. 1994. Is there a significant role for lipid peroxidation in the causation of malignancy and for antioxidants in cancer predvention. Cancer Res., 54: 19525-19565.

7. Duh , P.D. and G.C. Yen. 1997. Antioxidative activity of three herbal water extracts. Food Chem. 60 (4) : 639-642. 
8. Gazzani, G., A. Papetti, G. Massolini and M. Daglia. 1998. Anti and prooxidant activity of water soluble components of some common diet vegetables and the effect of thermal treatment. J.Agric. Food Chem., 46: 4118-4122.

9. Marbry, T.J., K.R. Markham and M.B. Thomas. 1970. The Systematic Identification of Flavonoids, Springer Verlage New Yourk, Heidelberg, Berlin.

10. Markham, K.R and T.J Mabry. 1968. The identification of twenty three 5-deoxy and ten 5 hydroxy flavonoid from Bapitsa leconti. Phytochem., 7, 1197.

11. Martinez - Valverde, I., M.J. Periago., G. Provan and A. Chesson. 2002. Phenolic compounds, lycopene and antioxidant activity in commerical varieties of tomato ( Lycopersicum esulentum). J.Sci. Food. Agric., 82: 323-330

12. Mizukoshi, M., T. Kawada and N. Matsui. 1979. Model studied of cake baking.1: continuous observation of strach gelatinization and protein coagulation during baking. Cereal Chem.56(4) : 305.

13. Rossell, J. B. 1983. In Rancidity in Food, ( Allen, J. C. and R. J. Hamilton), Applied Science pub, pp.21-47.

14. Shih, H., G.v. Pickwell and L.C. Quattrochi. 2000. Differential effects of flavonoid compounds on tumor promoter- induced activition of the human CYP1A2 enhancer. Arch. Biochem. Biophys., 373, 287-294.

15. Steel, G.D.R.and J.H. Torrie. 1980. Pirncipiles and procedures of statistics. Abiometrical approach. $2^{\text {nd }}$ Ed., Mc Graw- Hill, N.Y.

16. Tagi, K. 1987. Lipid peroxides and human diseases. Chem.Phys. Lipids., 45: 337-341

17. Tsuda , T.T., T.Osawa , T. Nakayama , S. Kawakishi and K. Ohshima. 1993. Antioxidant activity of pea bean ( Phaseolas vulgeris L.) extract. JAOCS., 70(9): 909.

18. Valle, M., M. Camara and M.E. Torija. 2006. Chemical characterization of tomato pomace. J.Sci. Food and Agric. 86(8) : 1232-1238. 
استخلاص المركبات البولي فينولية من قشور الطماطم كمضادات أكسدة طبيعية لحفظ جودة الكيك أثناء التخزين

$$
\begin{aligned}
& \text { رأفت نجيب سندق ، عبد المنعم صالح ابراهيم الثاذلي ، سهير طاهر الحديدي } \\
& \text { معهُ بحوث تكنولوجيا الاغذية - مركز البحوث الزراعية - جيزة - مصر }
\end{aligned}
$$

تم استخلاص المركبات الفلافونيدية والأحماض الفينولية من قثور الطماطم بواسطة كحول الايثايل

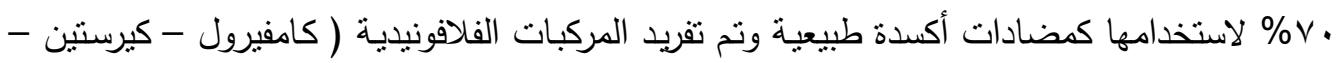
ليونين - نارجينين - ريوتن) والأحماض الفينولية ( بارا كيوماريك - فيريوليك - كلوروجينك ) بواسطة

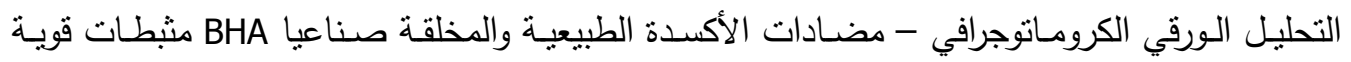

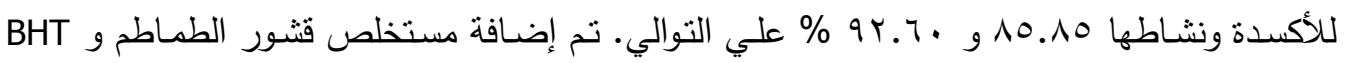

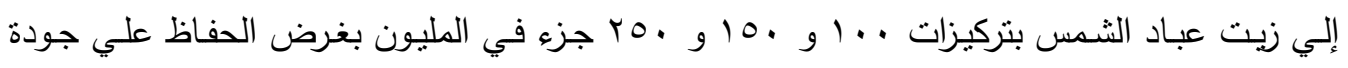

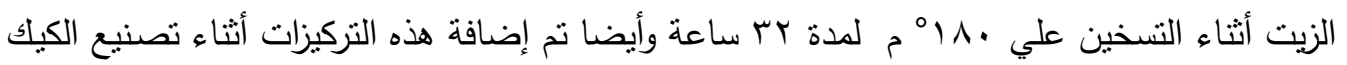

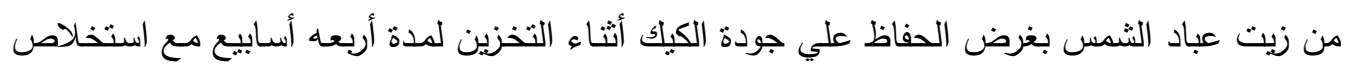
الزيت من الكيك كل أربعه أيام.

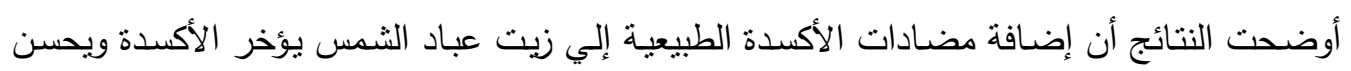
صفات الزيت كما يؤخر أيضا من عملية أكسدة الليبيدات أثناء تخزين الكيك. 